\title{
Problematic of Encroachment of Easement Areas in Lubumbashi/DRC, Public-Private Conflict: Status Report in the Reading of the Inter-Ministerial Order No. 0021 of October 29, 1993 Concerning the Application of the Regulations on Easements
}

\author{
Christian Bajima Wahelwe ${ }^{{ }^{*}}$, Serge Kalonji Muangala1', Joël Kwaleso Munanga1, \\ M'Zimbes Sophia Carole1, Olive Nkimba Mwanza', Lwamba Taki', Paul Tambani Muzita², \\ Martin Tshisuaka Nagalula ${ }^{2}$, Lukumwena Nsenda ${ }^{1,3}$

\footnotetext{
${ }^{1}$ Higher School of Architecture and Urbanism, New Horizons University, Lubumbashi, Democratic Republic of Congo ${ }^{2}$ Higher Institute of Architecture and Urbanism, Kinshasa, Democratic Republic of Congo

${ }^{3}$ Kobe Institute of Computing, Department of Information Technology, Kobe, Japan

Email: *chribaj2@gmail.com
}

How to cite this paper: Wahelwe, C.B., Muangala, S.K., Munanga, J.K., Carole, M.S., Mwanza, O.N., Taki, L., Muzita, P.T., Nagalula, M.T. and Nsenda, L. (2022) Problematic of Encroachment of Easement Areas in Lubumbashi/DRC, Public-Private Conflict: Status Report in the Reading of the Inter-Ministerial Order No. 0021 of October 29, 1993 Concerning the Application of the Regulations on Easements. Open Access Library Journal, 9: e8370.

https://doi.org/10.4236/oalib.1108370

Received: January 13, 2022

Accepted: February 13, 2022

Published: February 16, 2022

Copyright $\odot 2022$ by author(s) and Open Access Library Inc.

This work is licensed under the Creative Commons Attribution International License (CC BY 4.0).

http://creativecommons.org/licenses/by/4.0/

\begin{abstract}
The present work focuses our attention on the anarchic occupation of the easement zones in the city of Lubumbashi against the law texts on the matter, particularly the Inter-ministerial Decree No. 0021 of October 29, 1993 concerning the application of the regulation on easements. This first study was carried out on two samples of the City according to the contexts of old allotments inherited from colonization and allotments created after colonization. The objective is to identify the causes of these encroachments, to verify the level of applicability of the law under study and, with the help of professionals of the sector $(75 \%$ of the architects members of the Order of Architects in the Province having participated in the study), to suggest some avenues of reflection to be explored later on as sustainable solutions. The results of the surveys give us the following indications: $82 \%$ of the cases identified are the responsibility of the public authorities, while users are involved in $25 \%$ of the cases and $21 \%$ by the professionals of the sector. A table of recommendations is presented as avenues to explore to clean up the city whose management and use seem to be abandoned by all.
\end{abstract}

\section{Open Access}




\section{Subject Areas}

Architecture

\section{Keywords}

Easements, Law, Subdivision

\section{Introduction}

The street is the first school, it is the meeting place, it is the true meaning of life, says Louis Khan [1]. Its public character gives it a special status in socialization and therefore refutes any act of unilateral encroachment without authorization from the public authorities. Our study, carried out in two portions of housing estates in the city of Lubumbashi, is concerned with the existence of several cases of encroachment observed in the areas of easements at the edges of the road. Acts compromise certain characteristics of the street such as the place of transition and meetings, walkability, the passageways of Roads-Networks-Miscellaneous equipment...

According to different geographic areas, easement areas remain public spaces for all and are inalienable (Figure 1). For example:

In the French Department of Haute Garonne, a guide addressed to elected officials defines the communal public road domain [2]. The right-of-way is defined as the surface of the land belonging to the public entity and assigned to the road and its dependencies [2]. According to this guide, the public domain is assigned to a public use. It is unseizable and inalienable, imprescriptible, unclaimed and protected. The occupation of the public domain without authorization is subject to a road traffic violation and to prosecution (article L 116-1 to 8 and R.1 16-1 to 2 of the CVR) [2].

Closer to home, in Cameroon, Law No. 2004/003 of 21 April 2004 on the Town Planning Code specifies as: (Art.9.-1) unbuildable notably the parts of the

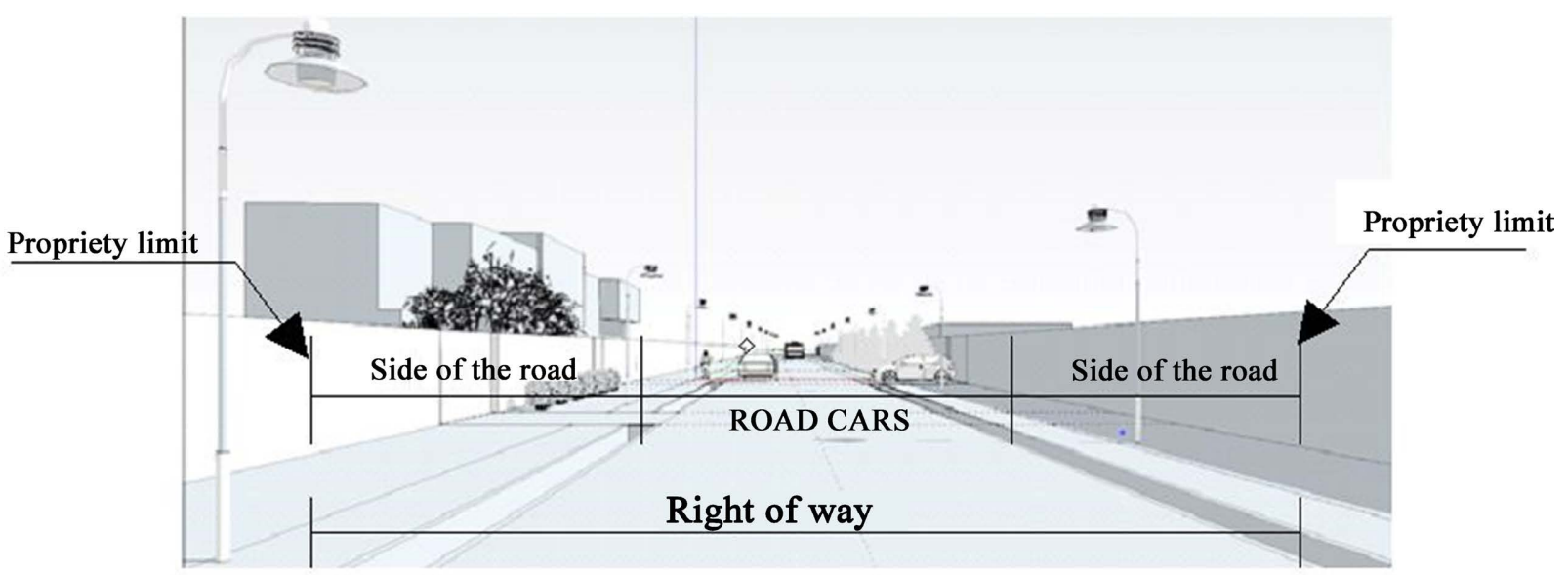

Figure 1. Limits of easement of the road and of the properties (ETS concept of architecture). 
public domain classified as such... [3]. In Section 3, on public utility easements affecting land use, Article 47 stipulates: 1) All the above defined urban planning documents must specify the public utility easements affecting land use. 2) Only the easements mentioned in the urban planning documents can be opposed to requests for land use authorization. 3) Article 55.3 the right-of-way of the roads, easements and public facilities provided for shall be returned to the public domain.

In the Democratic Republic of Congo, Inter-ministerial Order No. 0021 of 29 October 1993 on the application of the regulations on easements proposes a way of managing, in particular, the rights-of-way of public interest roads in accordance with urban plans and cadastral plans [4]. It is based on Law No. 13-021 of July 20,1913 on the general property regime, land and real estate regime and security regime, especially in its articles 169 to 180, 205 and 206, as amended and completed to date, and on the observation of the recrudescence of anarchic constructions in all the urban centers of the country [5].

This decree recognizes easements such as: green spaces; rights-of-way of public interest roads in accordance with urban plans and cadastral plans. All occupancy, construction and subdivision within the easements are prohibited. All constructions erected in violation of the provisions of this by-law as well as other legal or regulatory provisions on the subject shall be demolished at the expense of their builders or owners without any compensation. And finally, art. 4: The Secretaries General for Land Affairs, Urban Planning and Housing are responsible for the execution of the present decree which comes into force on the date of its signature [4].

\subsection{Issue and Background}

Since the post-conflict years of 1997, the city of Lubumbashi, the second largest city in the Democratic Republic of Congo, has experienced a significant horizontal expansion, with more than $80 \%$ of the housing built by private individuals as observed by Y. USENI et al, the proportion of built-up areas has progressively increased in the municipalities to the detriment of green spaces which have registered a regressive dynamic, as a consequence of a rapid demographic pressure coupled with the absence of an appropriate program for their preservation [6].

In this evolution, Bavon KILUMBA BANZE SILURE notes a significant number of irregularities in the management of the public domain as well as real estate and artificial furniture, easements of public utility in the city of Lubumbashi, a management which does not correspond to the aspirations of the public utility, which does not respect the prescriptions of the Law [7]. He notes as much as the easements are the most violated, they appear for the authorities as an elusive matter and difficult to manage [7].

Yet public space is defined by its accessibility. If it is challenged, it becomes difficult to call it public [8].

Are implicated by the law targeted by our study: the regulatory public author- 
ities and the users of the city, the population. A third induced actor is identified by Law No. 18/034 of DECEMBER 13, 2018 on the creation, organization and operation of the National Order of Architects, which intends in its Section 2, $\$ 1$ er, art. 4: The National Order of Architects has the following missions: 1. ensure order in the sector and guarantee the quality of the profession in order to protect Congolese society against architectural malpractice [9].

In this responsibility, the architect plays the role of bridge between the first two actors (Figure 2).

\subsection{Field of Studies and Method}

Our study proceeded by field observations, surveys in the form of conversations with inhabitants and submission of survey questionnaires to architects who are members of ONA/KATANGA.

Two samples of the fabric of the city of Lubumbashi were selected (Figure 3), in a comparative context of the city's development during the colonial period (heritage) and the post-colonial period (the city made by us):

Sample 1: Portion between Chaussée Laurent Désiré Kabila (South), Lumumba

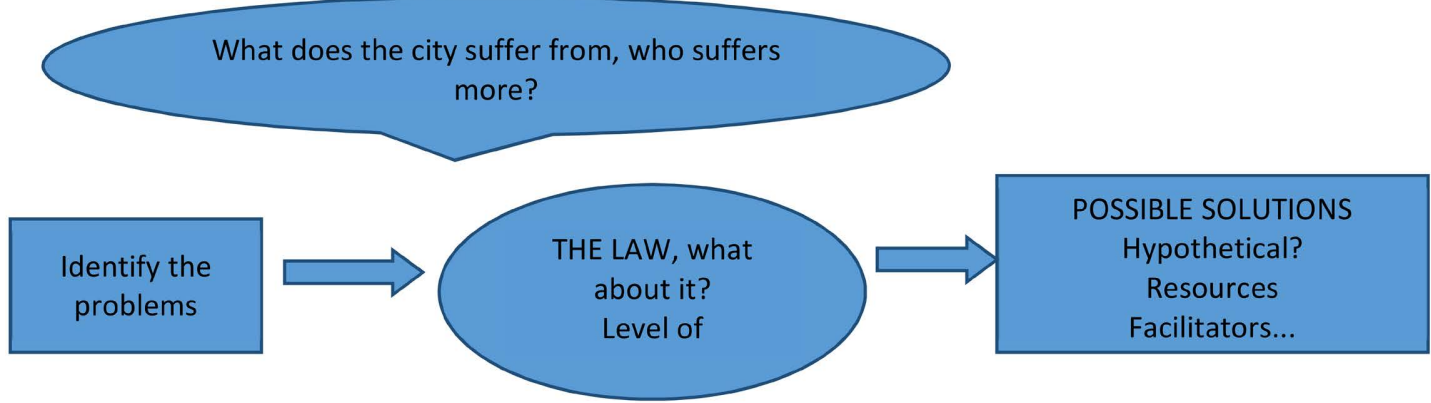

Figure 2. Study analysis diagram (architect LUKUMWENA NSENDA, PHD).

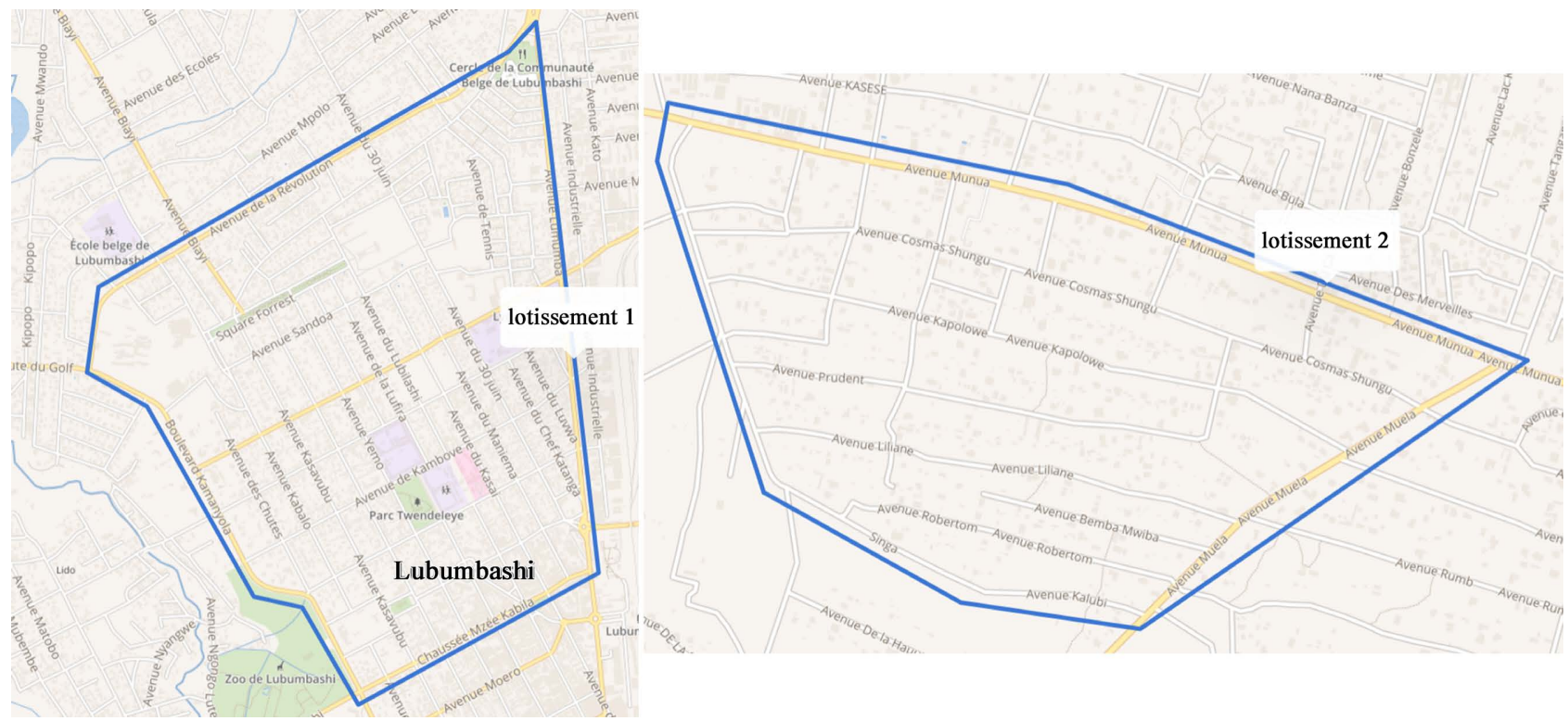

Figure 3. Portions of the considered subdivisions (source: https://maphub.net/map). 
(East), Revolution (North) and Kamanyola (West) avenues.

It is the result of the first urban development plan of the city, initiated by EMILE WANGERMEE, an engineering officer and the first administrator of the city. This plan covered an area of about 450 hectares, in the form of a quadrilateral squared by a grid of avenues intersecting at right angles [10]. The area retained is approximately $4.67 \mathrm{~km}^{2}$.

Sample 2: Post-colonial development, part of the extensions of the GOLF district, to the west of the city, progressing towards LUPOTO and even KIPUSHI.

The selected portion is between MUNUA (North), RUBI (East), bypass road (West) and the high voltage line (South) leading to GECEAMINES/STL and RUBI Avenue. The surface is about $3.2 \mathrm{~km}^{2}$.

\section{Results}

\subsection{Status Report}

In the subdivision inherited from colonization, the roads are fairly wide (average right-of-way of $10-35 \mathrm{~m}$ ), their layout still mostly regular but subject to encroachments in places. The originally residential subdivision is undergoing transformations towards formal commerce (which is becoming more and more important), administration, education and health.

On the other hand, in the new post-colonial neighborhoods, the road layout is often irregular due to the anarchic division of land. These new neighborhoods seem to suffer from a lack of urban planning. Here, more than in the first case, the setbacks are often invaded by private activities such as commerce, and developments in front of the plots, thus, outside the property limits. Other causes are also noted:

In both subdivisions, in the case of private development on easements, some respondents believe that these spaces constitute their extension of property onto the roadway, more than $90 \%$.

In this $1^{\text {st }}$ case, Graph 1 shows that small business (informal) and the development of plot frontages (veiled privatization) are the greatest causes of the problem (respectively $87 \%$ and $78.3 \%$ ). $56.5 \%$ of the cases even concern exclusive

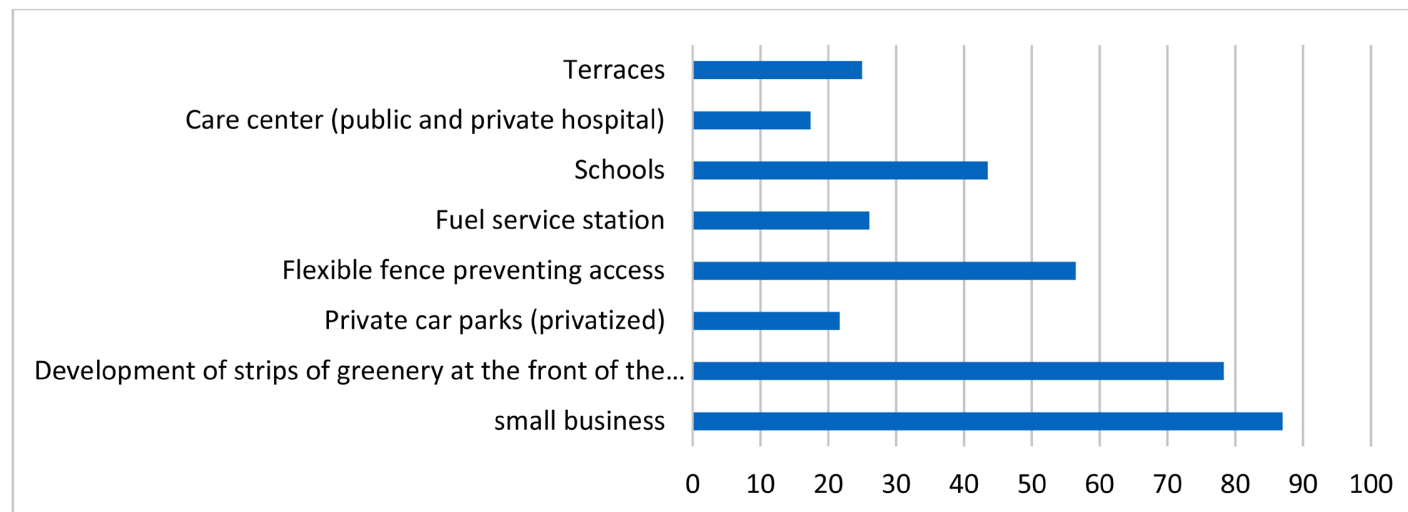

Graph 1. Encroachments on some important avenues of subdivision 1 according to their nature. 
fencing of these areas by private individuals, followed by schools (43.5\%), service stations $(26.1 \%)$, terraces (25\%), privatized parking lots (21.7\%) and health centers $(17.4 \%)$.

In the new subdivision, Graph 2 shows that the developments on the frontages of plots are visible on all the avenues visited (100\% of the cases); the overflow of plots from the general alignment on the avenue is also important in observation (88.89\% of the avenues visited know this case) and the small trade remains a need of the populations (77.78\%). We noted the same understanding of the populations, that the easements are extensions of the parcels according to the populations. Image 1 and Image 2 show some pictures of avenues visited and subject to encroachment.

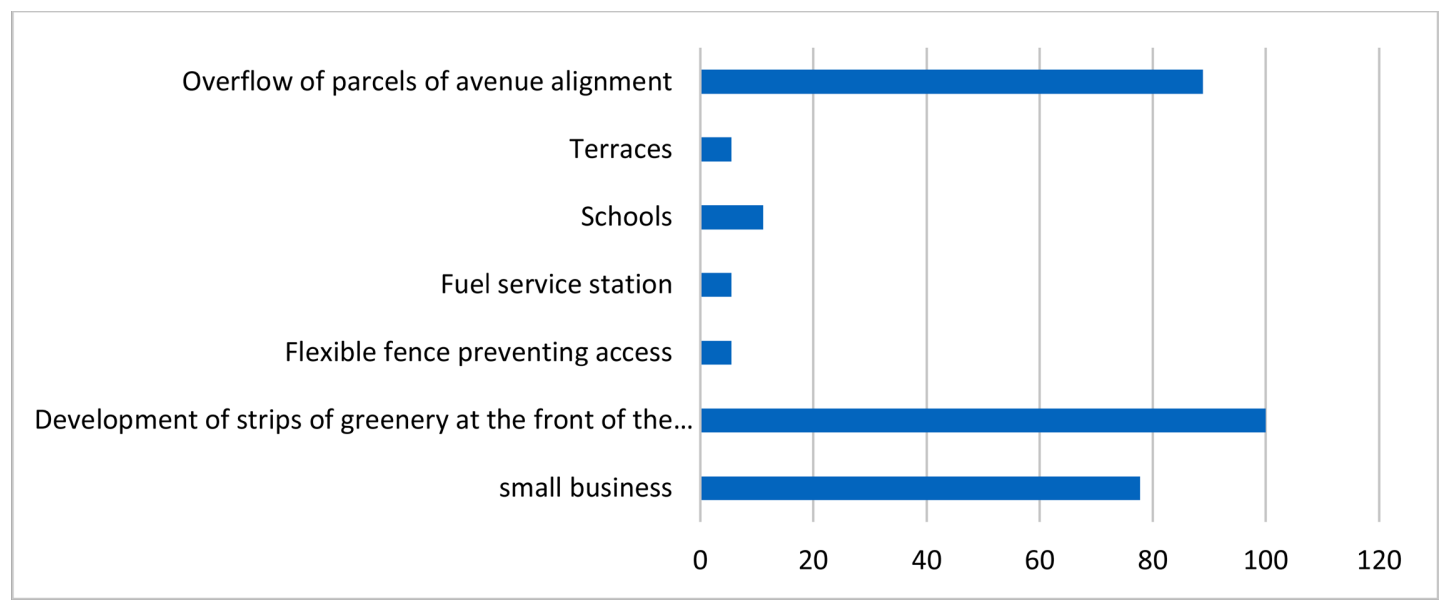

Graph 2. Encroachments on some important avenues in subdivision 2 according to their nature.
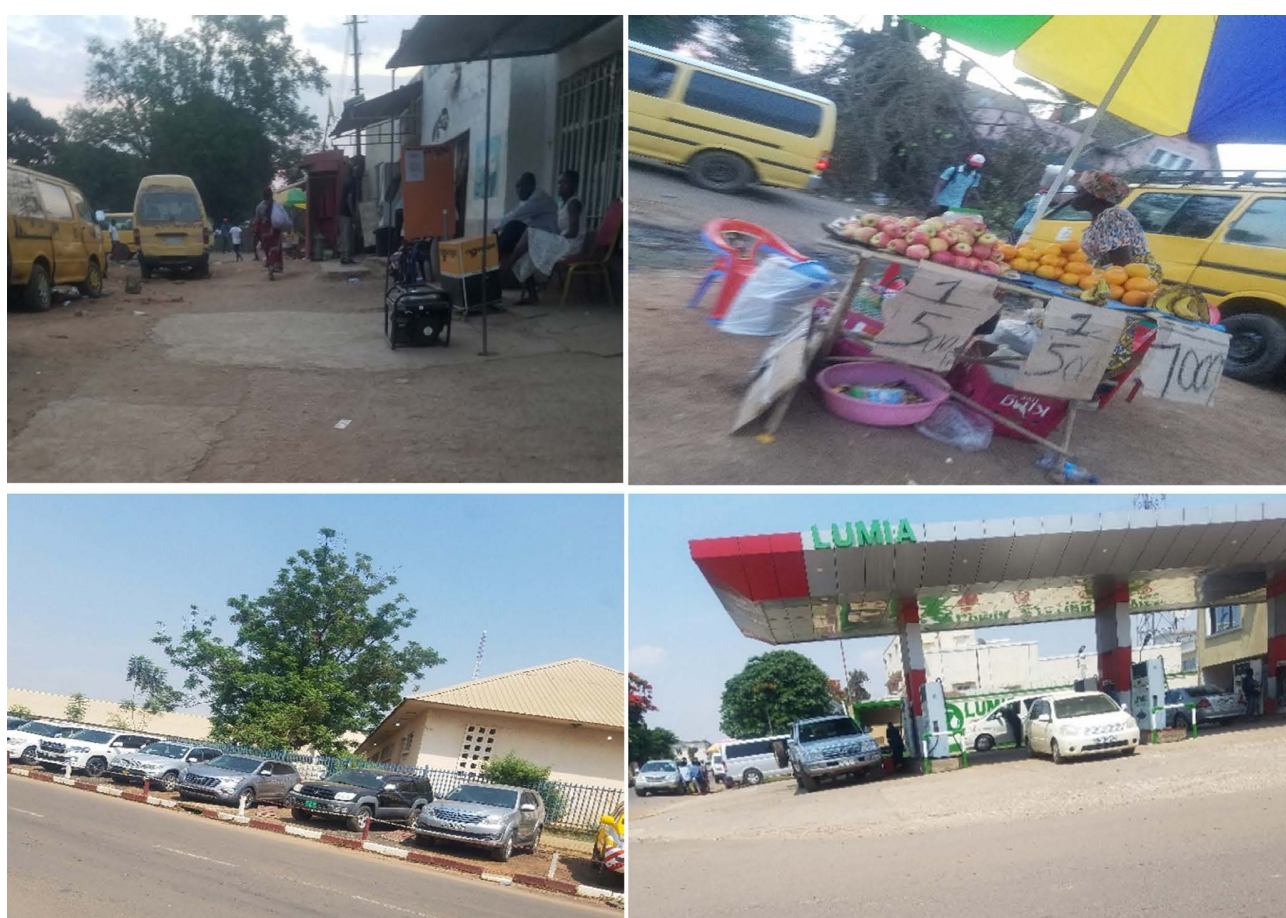

Image 1. Some images of avenues visited and subject to encroachment (subdivision 1). 

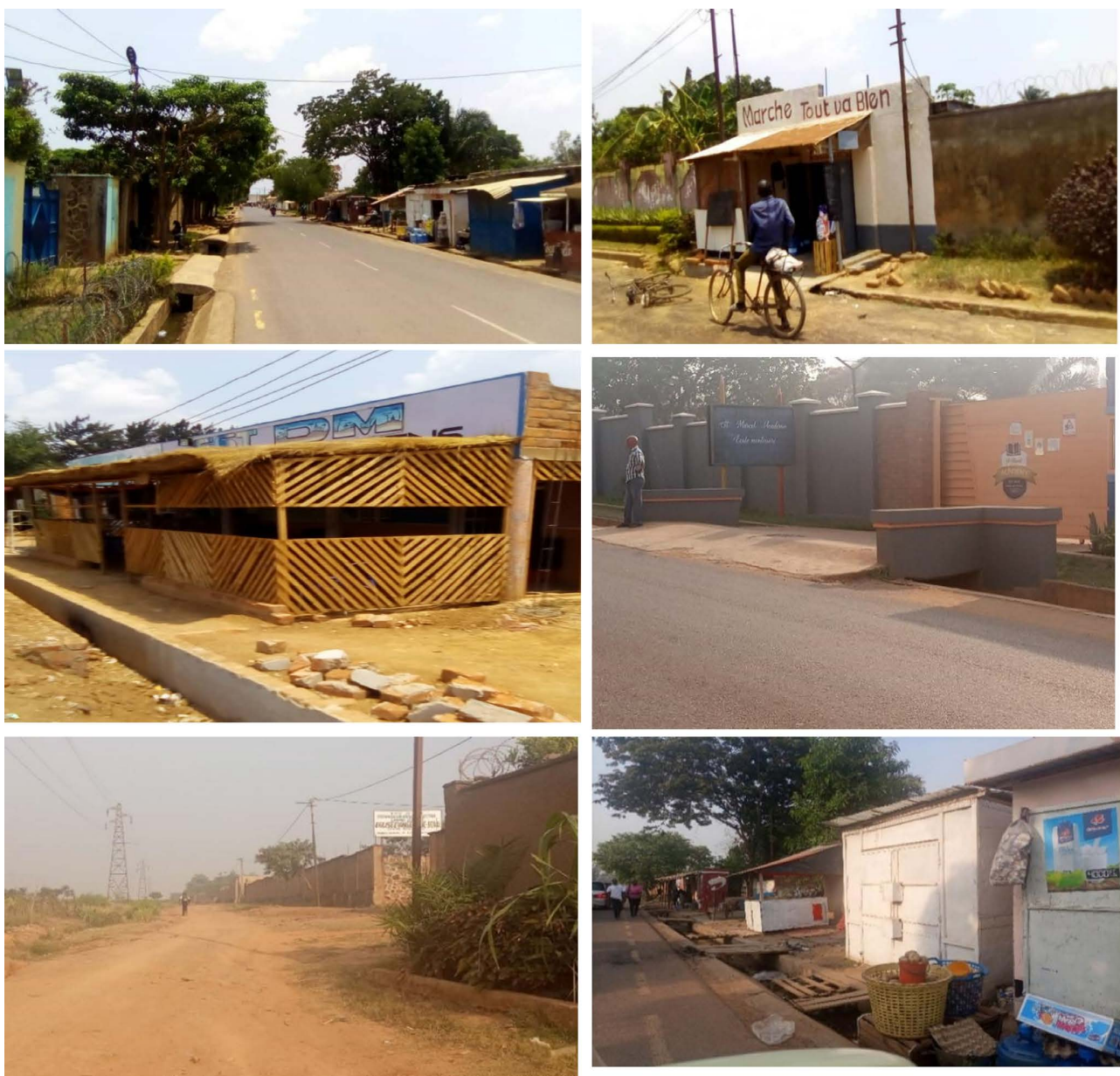

Image 2. Some images of avenues visited and subject to encroachment (subdivision 2).

\subsection{Causes of Encroachments}

The survey at this level concerned exclusively professionals, architects who are members of the National Order of Architects. Table 1 presents the descriptions of the causes identified after submission of a questionnaire-survey to said professionals. The responsibilities of the actors targeted in this study are indicated.

The professionals interviewed identified the most causes of the easement encroachment problem as being the responsibility of the public authorities (15 out of 25 cases are exclusive to them).

The cause shared concomitantly by the three actors concerns the conformism which pushes some to make as the others as well as the disorder generated by the non-execution on the ground of the regulation of the trade of the builders (case of the law on the ONA, ONI, ...).

The populations remain the active actors of these encroachments but the public authorities, by their laisser faire, carry the most responsibility on the causes.

\section{Findings}

$84 \%$ of the cases identified are the responsibility of the public authorities, while users are concerned by $2 \%$ of the cases as much as the professionals of the sector $(2 \%)$. 


\subsection{Knowledge and Practice of the Law by Professionals}

Of the 40 architects who are members of the Order of Architects in the Katanga Region, 30 responded to the questionnaire submitted to them in relation to the

Table 1. Causes of encroachment identified by professionals and responsibilities of stakeholders.

\section{RESPONSIBILITY}

OF THE ACTORS

\section{CAUSES FOUND AFTER INVESTIGATION}

State Population Professionals

1. The law dating from 1993 is no longer adapted to the current situation, the population is obliged to take charge of its own affairs.

2. Subdivisions do not follow any law and are not supervised by the ministry responsible for the $\mathrm{X}$ sector.

3. Ignorance of this law at the population level

4. Lack of follow-up and support in the application of the law by the public authorities

$\mathrm{X}$

5. The current trend of transforming the frontage of parcels or houses into commercial areas

6. Building permits are granted without real control

$\mathrm{X}$

7. Passivity, greed, ignorance of the authorities who must enforce the law. (CORRUPTION) X

8. Lack of willingness to put things in order $\quad \mathrm{X}$

9. Lack of passive outreach of the law $\quad \mathrm{X}$

10. Impunity and absence of state authority $\quad \mathrm{X}$

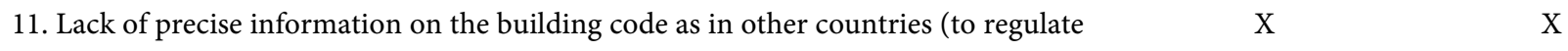
construction).

12. Lack of experience in our state services and professionals on the urban and architectural level $\mathrm{X}$

13. Lack of (financial) means for the work of public services

$\mathrm{X}$

14. The unwillingness of the population

15. Conformity (others do it, so it's normal)

16. Lack of public awareness

$\mathrm{X}$

$\mathrm{X}$

X

17. Lack of maintenance of its public spaces

$\mathrm{X}$

18. The violation of this one by the professionals of the land registry themselves, by subdivisions out of norms

19. The lack of mastery of the latter by construction professionals

20. The disorder caused by the non consideration of the competences recognized by the law (case of the law on the Order of Architects or Engineers for example)

21. The misery of the agents and civil servants of the state, as well as the two-speed justice

22. The abuse of certain public authorities, high ranking people in society.

23. Bicephalism of action of the two services of the Urbanism and the Cadastre in the implementation of the allotments

24. Politicization of sectors

$\mathrm{X} \quad \mathrm{X}$

25. Weakness of the services concerned

$\mathrm{X}$ 
present study, i.e. 75\% of the targeted people. The results are as shown in Table 2.

This table shows the level of mastery of the working framework by professionals ( $83 \%$ know the law); nevertheless, $24 \%$ of the respondents acknowledged having participated in the violation of the law; $48 \%$ consider that the violation of the law is normal given the general disorder in urban management, and even the complicity of the agents of the State who are supposed to enforce it. On the other hand, $90 \%$ of those consulted consider that the law is good and does not require any reorganization other than its strict application in the field, although the minority, the remaining $10 \%$, expect more recognition of the application of the law on the ONA.

In Table 3 in the appendix, the professionals suggested ways and means of

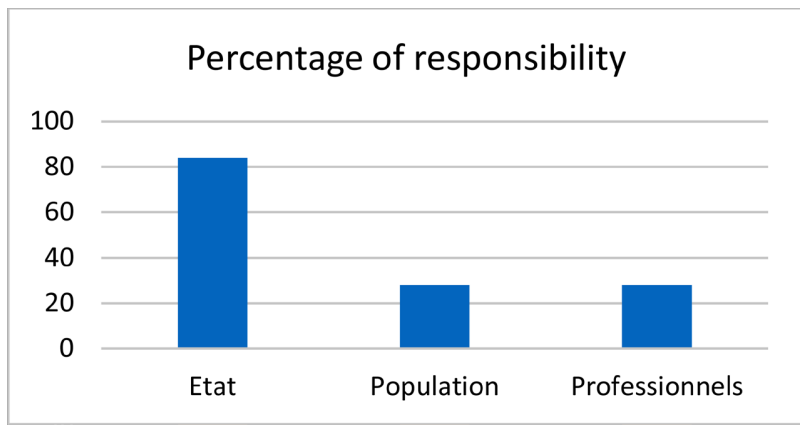

Graph 3. Responsibility of the actors in the causes identified.

Table 2. Knowledge and practice of the law by professionals.

\begin{tabular}{lcc}
\hline \multicolumn{1}{c}{ Points of attention raised } & $\begin{array}{c}\% \\
\text { (YES) }\end{array}$ & $\begin{array}{c}\% \\
\text { (NO) }\end{array}$ \\
\hline 1. Knowledge of the law under study & 83 & 17 \\
2. Participation in its implementation in the field & 62 & 38 \\
3. Participation at least once in its violation & 24 & 76 \\
4. Wish to participate in the amendment of the law & 10 & 90 \\
5. Find it normal not to be respected & 48 & 52 \\
\hline
\end{tabular}

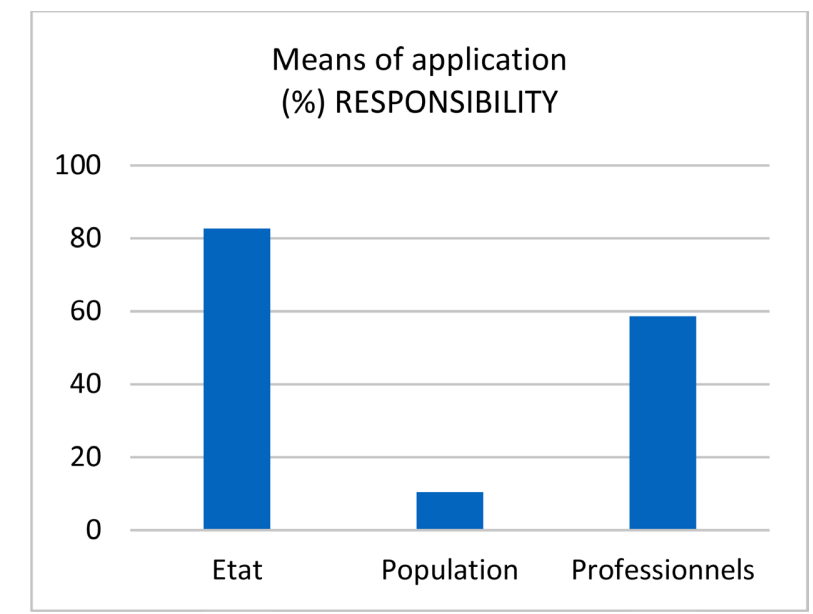

Graph 4. Ways and means of implementation of the law by the actors. 
Table 3. Ways and means suggested by professionals to enforce the law.

\section{MOYENS POUR FAIRE APPLIQUER LA LOI}

To adapt this law to the evolution of cities, to the reality of the subdivisions as a current phenomenon

2 Improving the treatment of law enforcement officers

3 Strictly enforce the ONA law

4 Apply deterrent measures to punish offenders and agents of the state services who participate in this disorder

Ensure the functioning of the Building Permit Commission (with a real control of the

5 construction files) and Respect the composition of the team analyzing the building permit application files

6 Increase the setback of buildings from easements (new subdivisions) Ensure the proper functioning of the planning offices in different neighborhoods to follow up on the different by-laws

8 Create standards for subdivisions based on lot size

Create a space for bicycle and pedestrian traffic to research how to decrease the amount of vehicle traffic in the urban space

10 Create a book or architectural document with graphic explanations for easy understanding by professionals and users

11 Establish a subdivision site monitoring police force headed by an expert in the field

Variant: monitoring commission including experts (architects and urban planners)

12 Avoid doing studies on these areas (for the attention of architects)

13 Update urban plans in the land department office through computer-assisted mapping to identify urban easement areas

14 Involve the public in maintaining these public spaces

15 Train or strengthen the capacities of state agents involved in supervision and monitoring in the field

16 Opt for penetrating markets to prevent sellers from ending up on the easement

17 Organize the effectiveness of the permanent presence and monitoring of the State in the field (supervision of services, precise objectives...)

18 Allow the erection of temporary occupancy in these areas while respecting certain prescriptions (particular design, duration of temporary occupancy, quality of materials, destination)

19 Promote well-established laws on space creation for 4-wheelers, 3-wheelers and 2-wheelers

20 Recruit qualified personnel (trained people) in the field (urban planner, architect)

21 Sensitize neighborhood leaders to ensure compliance with the law

22

To make the different actors aware of the law (architects, contractors, owners on the merits of respecting these prescriptions)

23 Ensure the maintenance of these spaces

24 Make the law sufficiently accessible to everyone (media, other means)

RESPONSABLES

State Population Professionals

$\mathrm{X}$

$\mathrm{X}$

$\mathrm{X}$

$\mathrm{X}$

$\mathrm{X}$

X

X

$\mathrm{X}$

$\mathrm{X}$

$\mathrm{X}$

$\mathrm{X}$

X

$\mathrm{X}$

$\mathrm{X}$

$\mathrm{X}$

$\mathrm{X}$

X

X

X

X

$\mathrm{X}$

X

X X

X
X

X

X

X

X

X

X

X

X

$\mathrm{X}$

X

X

X

$\mathrm{X}$<smiles>C1CCC1</smiles>

$\mathrm{X}$

X 


\section{Continued}

25 Participate with the public authorities in raising public awareness

26 Participate with public authorities in surveillance (ONA involved in the surveillance police)

enforcing the law: $83 \%$ of the suggested actions will be through the action of the public authorities, as a driving force for regulation and urban management; the contribution of professionals (59\%) is suggested as being of second importance and $10 \%$ of the means are the responsibility of the populations themselves.

Nearly $50 \%$ of the ways and means suggest that a partnership between the State and professionals be established as a basis for public action.

The consultation of the population makes it possible to find more sustainable solutions.

\section{Discussions}

\subsection{Critical Look at the Law}

Article 1 of the law under study defines easements as (among other things): green spaces; rights-of-way for roads of public interest in accordance with urban plans and cadastral plans.

Observation: The contrast of the two samples compared shows that the post-colonial subdivision did not follow a controlled process. The layout of the avenues was irregular. In both cases, the easements are most often alienated by private parties (90\% - 100\% of the avenues are concerned). The notion of public interest is therefore compromised. One of the important reasons raised is the lack of planning and respect of urban management rules (established).

Article 2 prohibits all occupancy, construction and subdivision within the easements as defined in article 1.

Observation: The facts on the ground show that this ban is little followed. No public action to remedy this has been observed. Some occupations, anarchic, are done with the agreement of (agents of) public services.

Article 3 provides for legal proceedings to be taken against offenders and for the demolition, at the expense of their builders or owners, without compensation, of all structures erected in violation of the provisions of this By-law and other legal or regulatory provisions in this regard.

Observation: Same as above.

Article 4 entrusts the General Secretaries of Land Affairs, Urban Planning and Housing with the execution of this decree, which is already in force.

Observation: The execution of this order is addressed only to the administrative services of the ministries concerned. In the field, the services concerned are unable to carry out their mission, or even overlap in terms of competencies. This is due to the low level of resources available for action in the field, the lack of motivation of staff and the lack of political will on the part of decision-makers. 
Also noted, the overlapping competencies of the monitoring and control teams at different levels: national (represented by the divisions), local (either of the City Hall, or of the neighborhoods)... the result being that nearly $70 \%$ of the cases of encroachment are due to the absence of State authority. Some occupations are even authorized at the level of the districts in contradiction with the present law.

\subsection{Discussion of the Results}

Regarding the Status report: $100 \%$ of the avenues visited are subject to the encroachments noted in Table 2 and Table 3. In general, the development on the frontages of the plots at the edges of the road (78\% in allotment 1 and $100 \%$ in allotment 2) and the small business (87\% in allotment 1 and $78 \%$ in allotment 2) appear as the first causes. They demonstrate the privatization of the private sector over the public sector, but also the social difficulties faced by the population. The other acts are consequences of this.

This high rate of violation of the easement zones is similar to an absence of the State on the ground, a management weakness already noted by the above-mentioned study [7].

The shared causes among the targeted actors in this study show that:

- Public authorities are highly concerned by $82 \%$ of the causes identified. They must rethink their urban governance;

- City users are involved in $25 \%$ of cases. A small percentage of cases does not exclude the responsibility of the population in the violation of easements. One of the important factors is social (see point 5 in Table 1). To this end, Paul TAMBANI recommends observing the spontaneous market in order to question, rethink and decolonize: the notion of public space, the notion of urban planning and infrastructure, the logic of development, the structuring of urbanization and urban governance [11].

Concerning the practice by professionals, $75 \%$ of the members of the Provincial Council of the Provincial Order of Architects/Katanga Region participated in the study. They are responsible for $21 \%$ of the cases identified by the surveys. In addition, $24 \%$ of professionals acknowledge having violated the law, often by force of the overall governance conditions or by pressure from their clients; \%17 do not know the law and \%38 have not had to advise on the application of the law in the field. On the other hand, $90 \%$ of those consulted believe that the law is good and does not need to be changed.

This last point of view suggests the involvement of professionals alongside the public authorities in order to participate in the regulation according to the law creating the National Order of Architects [9].

\section{Conclusions}

The present study identified cases of encroachment of easement areas in the city of Lubumbashi. It was carried out on two samples of the city: a housing estate 
Table 4. Summary of our recommendations. Without attributing a formal role to any of the entities mentioned, our table of suggestions to the various actors targeted by the study remains valid within the limits of the specific laws and the Territorial Organization in the Democratic Republic of Congo. It takes into account, in particular, the opinions noted in the above surveys and opens the way for further studies to be conducted specifically on the general problem identified in this study.

\begin{tabular}{ll}
\hline Recommendations & Facilitators
\end{tabular}

I. DESIRABLE REFORMULATION OF THE LAW

1) Decentralize sufficiently the execution and follow-up of the law by integrating in the statement of this law provisions of free application according to the cases by the local assemblies (City, Commune)

Interministerial decree Governments Assemblies

2) Integrate in the preamble of the law on easements, the statement of the law No. 18/034 on the National Order of Architects, in order to be updated to the context of existence of the ONA

\section{FIELD APPLICABILITY}

3) Bring back to the forefront of any urban action, especially of subdivision, the concerted

Public authorities PLANNING (STATE-POPULATION-EXPERTS) Ensure compliance with the regulations and revisit the regulations in force if necessary

Populations (local assemblies)

Professionals of the sector ${ }^{1}$

4) Reinvigorate the provincial building permit commission in order to monitor the mass and Public authorities situation plans as well as the specific plans for the development of the frontage of the parcels (to The order of Architects be submitted before construction for possible authorization)

5) Ensure the effectiveness of the actions of the urban control brigade in charge of enforcing the law on easements. Decentralize to the communal levels (districts)

6) For ongoing encroachments, revisit neighborhoods on a case-by-case basis in order to bring public utility areas back within their boundaries without necessarily evacuating small business occupations (take into account the social reality that justifies these occupations [11]).

7) Create frameworks for popularization and sensitization of the population. (media, local assemblies)

Urban planning at different level

Urban services: Urban planning, Environment The order of Architects

Public authorities The order of Architects Socio-community actors

8) Appoint a State Urban Architect for the City (role: advice and animation, supervision, control Public authorities and expertise in the central or deconcentrated services of the City and in the scientific, technical The order of Architects and cultural networks. He can also be in charge of teaching, research and project management missions... concerning the State services)

9) Initiate studies for the redevelopment of the city according to the neighborhoods or avenues most affected by private encroachment of setback areas. (PPA on a case-by-case basis). Articles under study.

Public authorities (city or municipal level) The order of Architects

${ }^{1}$ Opening to different potential socio-professional experts.

inherited from colonization and another developed after colonization. On the physical level, an apparent contrast differentiates them: the layout of the avenues and the quality of the plot division. In both cases the problem is visible. The main actions taken concern: small-scale commerce and veiled privatization justified by the embellishment of the frontages of private plots, outside the property limits.

The results discussed showed that the easements are seriously violated. The responsibilities are borne first by the public authorities, followed by the uncivilized actions of the populations as well as the poor accompaniment by the pro- 
fessionals of the sector, advisors of the first two actors. The latter have been the focus of this study.

This phenomenon destroys the public character of the street, spaces of transition for all but often alienated without the slightest call to order from the State which nevertheless holds a working tool: the Inter-ministerial Order No. 0021 of October 29, 1993 bearing application of the regulation on the easements.

Bruno Sabatier quoting the jurist C. Lavialle declares: "any human community needs, to exist as such, an open space, place of the social exchanges and also metaphor of the unity of the group" [12]. He thus reminds us of the importance of taking care of this social balance which promotes the character of public spaces for all and insists against any individual enjoyment. Thus the public-private conflict is reduced.

We have appended some of the solutions received from professionals to make the applicability of this law and its compliance more effective (Table 3) as well as our own corrective recommendations (Table 4).

\section{Conflicts of Interest}

The authors declare no conflicts of interest.

\section{References}

[1] Oussama, S. and Nadjette, D. (2012-2013) Presentation on the Architect: Louis Isidore Kahn. University Badji Mokhtar, Annaba.

[2] Direction départementale des Territoires de la Haute-Garonne, service Gestion des Territoires, Guide de gestion du domaine public routier.

[3] Cameroon, Law n ${ }^{\circ} 2004 / 003$ of April 21, 2004 on the Urbanism Code.

[4] Inter-Ministerial Decree $n^{\circ} 0021$ of October 29, 1998 Concerning the Application of the Regulation of Easements. http://www.leganet.cd/Legislation/Droitcivil/AM.021.29.10.1993. Easement.htm

[5] Journal officiel de la RDC, Numéro spécial $1^{\text {er }}$ Décembre 2004, Loi $n^{\circ} 73-21$ du 20 Juillet 1973 portant Régime général des biens, Régime foncier et immobilier et Régime des sûretés, telle que modifiée et complétée par la Loi 80-008 du 18 Juillet 1980.

[6] Sikuzani, Y.U., et al. (2017) Twenty-Five Years of Monitoring the Spatial Dynamics of Green Spaces in Response to Urbanization in the Communes of the City of Lubumbashi (Upper Katanga, D.R. Congo). Tropicultura [On Line], 35, 300-311. https://popups.uliege.be/2295-8010/index.php?id=1094

[7] Kilumba, B. (2009) The Decision-Making Process and Its Impact on the Management of the Public Domain in the City of Lubumbashi (in DRC). University of Lubumbashi, Lubumbashi (DRC).

[8] Morelle, M. (2006) “The Street” in the African City (Yaoundé, Cameroon and Antananarivo, Madagascar), in Annales de géographie 2006/4 (No. 650), 339-360.

[9] Official Gazette (2018) Law No. 18/034 of 13 DECEMBER 2018 on the Creation, Organization and Operation of the National Order of Architects, 59th Year Special Issue 26 December 2018. Kingdom of Belgium-Ministry of Colonies, L'urbanisme au Congo, les éditions de VISSCHER SPRL, 17 rue du Grand Cerf, Brussels, 211 p. 
[10] Kingdom of Belgium-Ministry of Colonies, L'urbanisme au Congo, les éditions de VISSCHER SPRL, 17 rue du Grand Cerf, Brussels, 211 p.

[11] Tambani Muzita, P. (2019-2020) The Dynamics of Spontaneous Markets: Foundation of Urban Structuring in the southwestern Periphery of Kinshasa. Towards a Governance of the "Wenze-Ville". ULB, Faculty of Architecture La Cambre Horta. Belgium.

[12] Sabatier, B. (2007) From the Impossible Public Space to the Publicization of Private Spaces. Guénola Capron and Nadine Haschar-Noé. L'espace public urbain: De l'objet au processus de construction. Presses Universitaires du Mirail, Toulouse, 276, Villes et territoires. ffhalshs-00348031. 